\title{
Productivity and carcass characteristics of lambs fed fibrous agricultural wastes to substitute grass
}

\author{
Endang Purbowati(i), C. M. Sri Lestari(i), Retno Adiwinarti(i), Vita Restitrisnani(i), Sri Mawati(i), \\ Agung Purnomoadi (iD and Edy Rianto (D)
}

\begin{abstract}
Department of Animal Sciences, Faculty of Animal and Agricultural Sciences, Diponegoro University, Campus Drh. Soejono Koesoemowardojo, Tembalang, Semarang 50275, Indonesia.

Corresponding author: Endang Purbowati, e-mail: purbowati@hotmail.com

Co-authors: CMSL: cmslest@yahoo.co.id, RA: retno_adi@yahoo.co.id, VR: restitrisnani.vita@gmail.com,

SM: mawati.undip@gmail.com, AP: agung194@yahoo.com,ER: erianto_05@yahoo.com

Received: 16-02-2021, Accepted: 29-04-2021, Published online: 17-06-2021
\end{abstract}

doi: www.doi.org/10.14202/vetworld.2021.1559-1563 How to cite this article: Purbowati E, Lestari CMS, Adiwinarti R, Restitrisnani V, Mawati S, Purnomoadi A, Rianto E (2021) Productivity and carcass characteristics of lambs fed fibrous agricultural wastes to substitute grass, Veterinary World, 14(6): 1559-1563.

\begin{abstract}
Background and Aim: Grass is often scarce for ruminants during the dry season in Indonesia; thus agricultural by-products are widely used as a substitute for grass. This study aimed to determine the effect of replacing Napier grass (NG) with agricultural by-products on the productivity and carcass characteristics of lambs.
\end{abstract}

Materials and Methods: Twenty-four 3-month-old male lambs with initial body weights of $13.26 \pm 1.29 \mathrm{~kg}$ (coefficient of variation $=9.73 \%$ ) were allocated into a completely randomized design with four treatments and six replications. The treatments included: $\mathrm{NG}=100 \% \mathrm{NG}$; corn cobs $(\mathrm{CCs})=50 \% \mathrm{NG}$ and $50 \% \mathrm{CCs}$; bagasse $(\mathrm{BG})=50 \% \mathrm{NG}$ and $50 \% \mathrm{BG}$; and peanut shells (PSs) $=50 \%$ NG and 50\% PSs. All treatment diets were pelleted and consisted of $40 \%$ fibrous feed and $60 \%$ concentrate feed, and contained $10.36-11.65 \%$ crude protein and $55.47-57.31 \%$ total digestible nutrients. Parameters observed included dry matter intake (DMI), dry matter digestibility, body weight gain (BWG), feed conversion ratio (FCR), feed cost per gain $(\mathrm{FC} / \mathrm{G})$, and carcass characteristics.

Results: Lambs fed the PSs diet had the highest $(\mathrm{p}<0.05)$ DMI $(781 \mathrm{~g} / \mathrm{d})$, digestibility, and body weight gain $(92.5 \mathrm{~g} / \mathrm{d}$; $\mathrm{p}<0.05$ ). The FCR of the PSs diet (9.13) was similar to NG. The FC/G of the PSs diet (IDR 23,541/kg) was the lowest of all diets. The BG diet had the lowest $(\mathrm{p}<0.05)$ digestibility, body weight gain $(54.4 \mathrm{~g} / \mathrm{d})$, and the highest (13.53) FCR. No significant differences ( $>0.05)$ were found in the carcass or meat characteristics of any diets. The averages of slaughter weight, carcass weight, and carcass percentage were $20.03 \mathrm{~kg}, 8.02 \mathrm{~kg}$, and $40.0 \%$, respectively. The average meat bone ratio was 3.67 .

Conclusion: It was concluded that agricultural wastes could be used as an alternative to NG at the level of $50 \%$ in the diet of lambs without a negative effect on production performance and carcass traits.

Keywords: bagasse, corn cobs, digestibility, feed efficiency, meat-bone ratio, peanut shells.

\section{Introduction}

Agricultural by-products are widely used for ruminant feed when grass is limited during the dry season in some countries. The use of agricultural waste as a source of fiber for ruminants can reduce feed prices and improve environmental sustainability using feed materials that are sustainably available. Examples of agricultural waste include corn cobs (CCs) [1-3], bagasse (BG) [4-7], and peanut shells (PSs) [8]. Ground CCs have been used as a fiber source in cows [1], goats [2], and lambs [3]. Babiker et al. [5] used BG for beef cattle, while Silva et al. [4], Filho et al. [6], and Galvani et al. [7] used it for lambs. Eshag et al. [8] used ground PSs for lambs to reduce feed cost.

Copyright: Purbowati, et al. Open Access. This article is distributed under the terms of the Creative Commons Attribution 4.0 International License (http://creativecommons.org/licenses/ by/4.0/), which permits unrestricted use, distribution, and reproduction in any medium, provided you give appropriate credit to the original author(s) and the source, provide a link to the Creative Commons license, and indicate if changes were made. The Creative Commons Public Domain Dedication waiver (http:// creativecommons.org/publicdomain/zero/1.0/) applies to the data made available in this article, unless otherwise stated.
Agricultural by-products are usually categorized as low-quality roughages due to their high crude fiber, neutral detergent fiber (NDF), and acid detergent fiber (ADF) contents. CCs contain $10.2 \%$ crude fiber, 38.0$79.9 \% \mathrm{NDF}$, and $16-40 \%$ ADF $[2,3]$. BG contains 84.6\% NDF and 53.1\% ADF [7]. PSs contain 43.9\%$80.5 \%$ crude fiber, $27.6-87 \% \mathrm{NDF}, 13.1-76.2 \% \mathrm{ADF}$, and $5.8-45.2 \%$ lignin [9]. These by-products have been processed into many dietary forms, such as ammoniated BG, BG treated with calcium oxide [6], ground maize cobs [1], and maize cob silage [3]. Wachirapakom et al. [1] used ground CCs as a single roughage source and found that ground $\mathrm{CCs}$ result in better dry matter intake (DMI) and milk yields compared to rice straw when used as a source of fiber in dairy cow diets. Treated agricultural by-products have additional positive effects on ruminants when used as a roughage source, including decreased methane emission in lambs [3] and improved nutrient intake and milk yield in lactating dairy, crossbred cows [1]. Complete feed or total mixed ration (TMR) is the ideal method to blend concentrate and roughage from 
local agricultural by-products to make a cheap and balanced ration [10]. Blended feed material in TMR can improve feed palatability [10-12], which allows unconventional feeds to be added that further reduce the price of the ration [10]. The forage and concentrate ratio in TMR can be formulated to meet the animals' nutritional requirements for the desired health status and production performance [12]. For example, Lin [12] found that equal amounts of proteins and carbohydrates in TMR maximize the fermentation activity of ruminal microbes and stabilize rumen $\mathrm{pH}$. The further processing of TMR into pellets increases feed intake and digestion [10]. Karimizadeh et al. [13] reported that the DMI of lambs fed pelleted TMR was higher than those fed mash TMR $(1.2 \mathrm{~g} / \mathrm{d}$ vs. $1.1 \mathrm{~g} / \mathrm{d}$, respectively). Islam et al. [14] also reported that pelleted TMR increased crude fiber digestibility compared to mash TMR. Ishaq et al. [15] found that lambs fed pelleted diets had an increased DMI of around $17 \%$ compared to those fed loose hay diets $(1.9 \mathrm{~kg} / \mathrm{d}$ vs. $1.6 \mathrm{~kg} / \mathrm{d}$, respectively), with a higher average daily gain (ADG; $0.24 \mathrm{~kg} / \mathrm{d}$ vs. $0.08 \mathrm{~g} / \mathrm{d}$, respectively).

This study investigated the use of agricultural by-products as a component of pelleted lamb feed to increase productivity and reduce feed costs (FC), since agricultural by-products are abundantly available to substitute grass and may be best utilized as pellets.

\section{Materials and Methods}

\section{Ethical approval}

The animal handling and scientific procedures in this study were approved by the Animal Ethics Committee from the Faculty of Animal and Agricultural Science, Diponegoro University, Indonesia.

\section{Study period and location}

The study was conducted from July to December 2019 at the Research Farm of Meat and Dairy Production Laboratory, Department of Animal Science, Faculty of Animal and Agricultural Sciences, Diponegoro University, Semarang, Indonesia.

\section{Animals, experimental design, and treatments}

The study used 24, 3-month-old male lambs with an average body weight of $13.26 \pm 1.29 \mathrm{~kg}$ (coefficient of variation $=9.73 \%$ ). The lambs were allocated into a completely randomized design [16] with four treatments and six replications. The diets contained three different agricultural by-products (i.e., CCs, BG, and PSs) as a fiber source to substitute Napier grass (NG). The concentrate consisted of rice bran, cassava waste product, soybean meal, molasses, and minerals. The diets consisted of $40 \%$ fibrous feedstuffs and $60 \%$ concentrate, and were formulated to contain 10.36$11.65 \%$ crude protein and $55.47-57.31 \%$ total digestible nutrients (TDN) (Table-1) [17]. The diets were offered to the animals in pellet form. The treatments included $\mathrm{NG}=100 \% \mathrm{NG}$ (with no agricultural wastes); $\mathrm{CCs}=50 \% \mathrm{NG}$ and $50 \% \mathrm{CCs} ; \mathrm{BG}=50 \% \mathrm{NG}$ and $50 \%$ $\mathrm{BG}$; and $\mathrm{PSs}=50 \% \mathrm{NG}$ and $50 \% \mathrm{PSs}$.
Table-1: Feed composition and nutritional content of the diets.

\begin{tabular}{lcccc}
\hline $\begin{array}{l}\text { Feed composition/ } \\
\text { nutritional content }\end{array}$ & NG & CCs & BG & PSs \\
\hline Feed composition (\%) & & & & \\
Napier grass & 40.00 & 20.00 & 20.00 & 20.00 \\
Corn cobs & 0.00 & 20.00 & 0.00 & 0.00 \\
Bagasse & 0.00 & 0.00 & 20.00 & 0.00 \\
Peanut shell & 0.00 & 0.00 & 0.00 & 20.00 \\
Rice bran & 34.05 & 34.05 & 34.05 & 34.05 \\
Cassava waste products & 5.00 & 5.00 & 5.00 & 5.00 \\
Soybean meal & 12.95 & 12.95 & 12.95 & 12.95 \\
Molasses & 6.00 & 6.00 & 6.00 & 6.00 \\
Mineral mix & 2.00 & 2.00 & 2.00 & 2.00 \\
Nutritional content (\%) & & & & \\
Dry matter & 92.20 & 92.42 & 92.14 & 92.17 \\
Ash & 9.75 & 8.85 & 8.46 & 9.96 \\
OM & 90.25 & 91.15 & 91.54 & 90.04 \\
CP & 11.65 & 10.73 & 10.36 & 10.41 \\
EE & 5.55 & 6.08 & 5.19 & 5.23 \\
CF & 31.43 & 33.16 & 34.81 & 37.46 \\
NFE & 41.62 & 41.18 & 41.18 & 36.94 \\
TDN & 56.48 & 57.31 & 55.47 & 55.77 \\
NDF & 55.83 & 57.61 & 54.47 & 56.76 \\
ADF & 27.38 & 29.63 & 31.20 & 32.15 \\
Price (IDR/kg) & 2,352 & 2,352 & 2,331 & 2,377 \\
\hline NG & & & \\
\hline
\end{tabular}

NG $=100 \%$ Napier grass, CCs $=50 \%$ Napier grass and $50 \%$ corn cobs; $B G=50 \%$ Napier grass and $50 \%$ bagasse, $\mathrm{PSs}=50 \%$ Napier grass and $50 \%$ peanut shells, TDN was calculated from the formula TDN=digested $\mathrm{CP}+(2.25 \times$ digested $\mathrm{EE})+$ digested $\mathrm{CF}+$ digested NFE [17]. $\mathrm{OM}=$ Organic matter, $\mathrm{CP}=$ Crude protein, $\mathrm{EE}=\mathrm{Ether}$ extract, $\mathrm{CF}=$ Crude fiber, NFE=Nitrogen-free extract, $T D N=$ Total digestible nutrients, NDF=Neutral detergent fiber, $A D F=$ Acid detergent fiber

\section{Observed variables, research activities, and procedures}

The examined variables included lamb productivity and carcass characteristics (i.e., DMI, organic matter intake (OMI), dry matter digestibility (DMD), organic matter digestibility (OMD), body weight gain (BWG), feed conversion ratio (FCR), FC per gain $(\mathrm{FC} / \mathrm{G})$, carcass traits, carcass composition (bones, meat, and fat), and meat-bone ratio). The experimental period consisted of five stages: Preparation (3 weeks), adaptation (3 weeks), the preliminary period (1 week), the treatment period (12 weeks), and slaughtering. The lambs were provided the diets and water ad libitum and were weighed once a week. Feces were collected for 7 days during week 3 of the treatment period to calculate feed digestibility [18]. The feces were collected daily, weighed, and sampled using the procedure of Darlis et al. [19]. After the 12-week treatment period, the lambs were fasted for $12 \mathrm{~h}$ with free access to freshwater, and then slaughtered. The carcasses were weighed and separated for bone, fat, and meat according to Pratiwi et al. [20]; however, in this study, the kidneys were included in the carcasses.

\section{Statistical analysis}

The data obtained were analyzed using analysis of variance, apart from the $\mathrm{FC} / \mathrm{G}$, which was analyzed descriptively. Duncan's multiple range test was applied 
when there were differences among the treatments [16]. The level of significance was based on $p<0.05$.

\section{Results}

\section{Lamb's productivity}

The effect of NG substitution by agricultural by-products on lamb productivity is presented in Table-2. The DMI and OMI of the lambs fed the PSs diet were significantly higher $(\mathrm{p}<0.05)$ than the other diets, although the DMI in the percentage of body weight was not significantly different $(p>0.05)$ among the treatments. The crude protein intake (CPI) of lambs fed the PSs and NG diets was higher $(p<0.05)$ than that of the CCs- and BG-fed lambs. The CPI of the lambs fed the PSs and NG diets was not significantly different ( $p>0.05)$. The crude fiber intake (CFI) of the lambs fed the NG diet was the lowest. The TDN intake of the lambs fed the NG and BG diets was lower than that of those fed the PSs diet. The TDN intake of the lambs fed the CCs diet was not significantly different ( $p>0.05$ ) from those fed the NG, BG, and PSs diets.

The DMD and OMD of the PSs diet were higher $(p<0.05)$ than those of the CCs and BG diets, but were not significantly different $(p>0.05)$ from those of the NG diet. There was no significant difference $(\mathrm{p}>0.05)$ in DMD and OMD for the NG, CCs, and BG diets. The digestible DMI and OMI in the PSs group had the highest value $(p<0.05)$.

The BWG of the lambs fed the PSs diet was higher $(p<0.05)$ than those fed the CCs and BG diets, but was not significantly different $(p>0.05$ ) from those fed the NG diet. The lambs fed the NG diet had higher $(\mathrm{p}<0.05)$ BWG than those fed the BG diet; however, there was no significant difference $(\mathrm{p}>0.05)$ in $\mathrm{BWG}$ between the lambs fed the NG and CCs diets, or between the lambs fed the CCs and BG diets (Table-2). Consequently, the FCR was lowest in the PSs-fed lambs and highest in the BG-fed lambs $(p<0.05)$. The BWG and FCR results influenced the FC/G. The lambs fed the PSs diet had the lowest FC/G, followed by those fed the NG, CCs, and BG diets, respectively.

\section{Lamb carcass characteristics}

The effect of NG substitution by agricultural wastes on lamb carcass characteristics is presented in Table-3. No significant differences $(\mathrm{p}>0.05)$ were found between the different treatments for any of the measured lamb carcass characteristics. The average slaughter weight was $20.03 \mathrm{~kg}$, which produced $8.02 \mathrm{~kg}$ carcass weight and $4.50 \mathrm{~kg}$ meat. The average carcass bone weight was $1.74 \mathrm{~kg}$. The meat-bone ratio was 3.67 on average.

\section{Discussion}

\section{Feed intake, digestibility, BWG, FCR, and economic implications}

The feed intake and digestibility influenced lamb productivity. The PSs-fed lambs had the highest DMI, OMI, and TDN intake values. These findings could be attributed to the high DMD and OMD of the PSs diet. The high DMI and DMD of the PSs diet led to high
Table-2: Productivity of lambs fed diets with different sources of fiber.

\begin{tabular}{|c|c|c|c|c|}
\hline Variables & NG & CCs & BG & PSs \\
\hline Dry matter intake ( $\mathrm{g} /$ days) & $724^{a}$ & $722^{\mathrm{a}}$ & $718^{\mathrm{a}}$ & $781^{\mathrm{b}}$ \\
\hline Dry matter intake (\% BW) & 4.42 & 4.44 & 4.50 & 4.73 \\
\hline $\begin{array}{l}\text { Organic matter intake } \\
\text { (g/days) }\end{array}$ & $654^{a}$ & $658^{a}$ & $657^{a}$ & $704^{b}$ \\
\hline Crude protein intake(g/days) & $84^{b}$ & $76^{a}$ & $74^{\mathrm{a}}$ & $81^{\mathrm{b}}$ \\
\hline Crude fiber intake (g/days) & $228^{\mathrm{a}}$ & $240^{\mathrm{b}}$ & $250^{\mathrm{b}}$ & $293^{c}$ \\
\hline TDN intake (g/days) & $410^{\mathrm{a}}$ & $416^{\mathrm{ab}}$ & $398^{a}$ & $435^{b}$ \\
\hline Dry matter digestibility (\%) & $51.9^{\mathrm{ab}}$ & $51.4^{\mathrm{a}}$ & $50.9^{a}$ & $53.0^{\mathrm{b}}$ \\
\hline $\begin{array}{l}\text { Digestible dry matter intake } \\
\text { (g/days) }\end{array}$ & $376^{b}$ & $372^{\mathrm{ab}}$ & $365^{a}$ & $414^{c}$ \\
\hline $\begin{array}{l}\text { Organic matter digestibility } \\
(\%)\end{array}$ & $55.9^{\mathrm{ab}}$ & $53.9^{a}$ & $52.8^{a}$ & $62.1^{\mathrm{b}}$ \\
\hline $\begin{array}{l}\text { Digestible organic matter } \\
\text { intake ( } \mathrm{g} / \text { days) }\end{array}$ & $367^{a}$ & $355^{a}$ & $347^{a}$ & $437^{b}$ \\
\hline ain (g/days) & $77.5^{\mathrm{bc}}$ & $68.2^{\mathrm{ab}}$ & $54.4^{\mathrm{a}}$ & $92.5^{c}$ \\
\hline Feed c & $9.7^{\mathrm{a}}$ & $11.2^{\mathrm{ab}}$ & $13.5^{\mathrm{b}}$ & $9.1^{\mathrm{a}}$ \\
\hline Feed cost per gain (IDR/kg) & 24,835 & 28,554 & 34,234 & 23,541 \\
\hline
\end{tabular}

$\mathrm{a}, \mathrm{b}, \mathrm{c}$ Within a row, means without a common uppercase superscript differ $(p<0.05)$. NG $=100 \%$ Napier grass, CCs $=50 \%$ Napier grass and $50 \%$ corn cobs; $B G=50 \%$ Napier grass and $50 \%$ bagasse, PSs $=50 \%$ Napier grass and $50 \%$ peanut shells. $\mathrm{BW}=$ Body weight

Table-3: Carcass production and characteristics of lambs fed diets with different sources of fiber.

\begin{tabular}{|c|c|c|c|c|c|}
\hline Variables & NG & CCs & BG & PSs & Average \\
\hline Slaughter weight (kg) & 20.22 & 19.82 & 19.26 & 20.84 & 20.03 \\
\hline Carcass weight $(\mathrm{kg})$ & 8.40 & 7.88 & 7.46 & 8.34 & 8.02 \\
\hline $\begin{array}{l}\text { Dressing percentage } \\
(\%)\end{array}$ & 41.5 & 39.9 & 38.7 & 40.1 & 40.0 \\
\hline \multicolumn{6}{|l|}{ Carcass components } \\
\hline Meat weight (g) & 4,79 & 4,53 & 4,21 & 4,45 & 4,50 \\
\hline Meat percentage (\%) & 57.1 & 57.6 & 56.2 & 53.3 & 56.0 \\
\hline Bone weight (g) & 1.755 & 1.663 & 1.672 & 1.868 & 1.740 \\
\hline Bone percentage (\%) & 21.1 & 21.2 & 22.6 & 22.5 & 21.9 \\
\hline Fat weight $(\mathrm{g})$ & 1.466 & 1.321 & 1.253 & 1.654 & 1.423 \\
\hline Fat percentage (\%) & 17.3 & 16.5 & 16.9 & 19.8 & 17.6 \\
\hline $\begin{array}{l}\text { Connective tissue } \\
\text { weight }(\mathrm{g})\end{array}$ & 385 & 367 & 321 & 368 & 360 \\
\hline $\begin{array}{l}\text { Connective tissue } \\
\text { percentage }(\%)\end{array}$ & 4.6 & 4.7 & 4.3 & 4.4 & 4.5 \\
\hline \multicolumn{6}{|l|}{$\begin{array}{l}\text { Distribution of carcass } \\
\text { fat }\end{array}$} \\
\hline $\begin{array}{l}\text { Subcutaneous fat } \\
\text { weight }(\mathrm{g})\end{array}$ & 836 & 695 & 723 & 979 & 808 \\
\hline $\begin{array}{l}\text { Subcutaneous fat } \\
\text { percentage (\%) }\end{array}$ & 57.1 & 50.5 & 57.5 & 59.2 & 56.1 \\
\hline $\begin{array}{l}\text { Intermuscular fat } \\
\text { weight }(\mathrm{g})\end{array}$ & 487 & 485 & 395 & 463 & 457 \\
\hline $\begin{array}{l}\text { Intermuscular fat } \\
\text { percentage }(\%)\end{array}$ & 33.0 & 39.0 & 31.7 & 28.5 & 33.1 \\
\hline Kidney fat weight (g) & 91 & 92 & 90 & 127 & 100 \\
\hline $\begin{array}{l}\text { Kidney fat percentage } \\
(\%)\end{array}$ & 6.5 & 6.7 & 7.1 & 7.4 & 6.9 \\
\hline Pelvic fat weight (g) & 51 & 49 & 46 & 84 & 58 \\
\hline $\begin{array}{l}\text { Pelvic fat percentage } \\
(\%)\end{array}$ & 3.5 & 3.8 & 3.6 & 4.9 & 3.9 \\
\hline \multicolumn{6}{|l|}{ Meat-bone ratio } \\
\hline Meat-bone ratio & 3.86 & 3.78 & 3.47 & 3.59 & 3.67 \\
\hline Lean meat-bone ratio & 3.00 & 2.98 & 2.72 & 2.65 & 2.84 \\
\hline
\end{tabular}

$\mathrm{NG}=$ Napier grass, CCs $=50 \%$ Napier grass and $50 \%$ corn cobs, $B G=50 \%$ Napier grass and $50 \%$ bagasse, $P S s=50 \%$ Napier grass and $50 \%$ peanut shells

DDMI, which, in turn, caused the lambs fed the PSs diet to have the highest BWG and lowest FCR, with 
the cheapest FC/G. The lambs fed the diet containing BG had the lowest BWG. The BWG of the lambs fed the NG diet was similar to those fed the CCs and PSs diets. These results agree with Santos et al. [21] who found that BWG was affected by DMI.

The high NDF and ADF contents (Table-1) in the agricultural by-product diets did not significantly decrease lamb productivity. Usually, the higher NDF and ADF contents cause lower feed intake [21]. We speculate that the PSs and CCs were more palatable in this study, since the inclusion of these feedstuffs did not reduce DMI in the lambs. Another explanation may be that the ingredients were all ground, then offered to the animal in pelleted form. Khan et al. [22] stated that grinding and pelleting feeds break down cell walls, reduce particle sizes, increase feed density, increase rumen passage rates, and increase DMI. The inclusion of concentrate in the diet improved the nutrient digestibility of the low-quality crop residues, increased growth rate and meat production $[23,24]$, and reduced $\mathrm{FC} / \mathrm{G}$ compared to conventional feeding systems [24]. Karimizadeh et al. [13] reported that the digestibility of pelleted complete feed was higher than that of mash complete feed.

\section{Carcass characteristics}

The substitution of NG by agricultural wastes did not affect slaughter weight, carcass production, meat production, meat-bone ratio, or subcutaneous fat thickness in lambs. These findings were attributed to the fact that the slaughter weights of the lambs fed with different diets were similar.

The above results indicate that $\mathrm{CCs}, \mathrm{BG}$, and PSs could be used to substitute NG without a negative effect on production. Similar slaughter weights were associated with similar carcass weights and dressing percentages, as already pointed out by Sabbioni et al. [25]. The carcass weight was affected by the slaughter weight. The carcass weights obtained in this study were similar to those reported by Setyaningrum et al. [26], where Indonesian thin-tailed sheep weighing 17.5-18.8 $\mathrm{kg}$ produced 7.7-8.5 $\mathrm{kg}$ carcasses. Other studies reported that lamb carcass weights varied from $15.3 \mathrm{~kg}$ to $26.1 \mathrm{~kg}$ when originating from a slaughter weight of $34.3 \mathrm{~kg}-54.1 \mathrm{~kg}$ [21,27-30]. Forwood et al. [30] reported that heavier live weights produced higher carcass weights and dressing percentages. Dressing percentages in this study $(40.03 \%)$ were similar to those reported by Setyaningrum et al. [26] in thin-tailed sheep. The previous studies reported that the dressing percentages of different lamb breeds varied from $39 \%$ to $51 \%$ [21,25,26,29,30]. Valizadeh et al. [31] showed that the heavier the body weight of the lamb, the higher its carcass percentage.

In general, consumers prefer meat with less fat [32]. Carcass fat percentage in this study $(17.61 \%)$ was similar to those reported by Santos et al. [21] (i.e., 15-18\%) and Obeidat et al. [27] (i.e., 16.6-20.1\%). Lambs with lighter body weight than mutton contain less carcass fat trimming, as reported by Sabbioni et al. [25] who found that lamb fat trimmings were $13.04-17.31 \%$, whereas those in mutton were $15.96-19.06 \%$. Thus, consumers believe that lighter lambs produce healthier meat [32]. In fact, Ekiz et al. [33] reported that the lean fat ratios of low, medium, and high weight groups $(26 \mathrm{~kg}, 30 \mathrm{~kg}$, and $35 \mathrm{~kg}$ ) of lambs were similar (3.93-4.25) with a total fat content of $15.24 \%-16.81 \%$.

Meat-bone ratio is an important parameter because it is related to the edible portion of the carcass. The meat-bone ratio in this study (3.67) was higher than that in Awassi lambs fed up to $300 \mathrm{~g} / \mathrm{kg}$ layer litter (2.95-3.10) [27], Cornigliese lambs (2.22-3.09), and mutton (3.25-3.52) [25]. The lean meat-bone ratio in this study (2.84) was lower than that reported by Ekiz et al. [33] (3.13-3.48).

\section{Conclusion}

It can be concluded that agricultural wastes, namely, CCs, BG, and PS, can be used to substitute grass as a component of lamb diets at the level of $50 \%$ without a negative effect on production performance and carcass traits. The use of PSs to substitute NG increased lamb productivity. Carcass trait characteristics were not affected by agricultural wastes.

\section{Authors' Contributions}

EP and AP: Designed the study, interpreted the data, and drafted the manuscript. ER, RA, CMSL, and SM: Participated in study design and contributed to the preparation and critical review of this manuscript. RA and VR: Did statistical analysis and drafted the manuscript. All authors read and approved the final manuscript.

\section{Acknowledgments}

This research was funded by "Selain APBN" Grant number: 43/UN7.5.5/PP/2019 of Faculty of Animal and Agricultural Sciences, Diponegoro University, Semarang, Indonesia. The authors also thank Dr. S. Sugiharto for editing the manuscript.

\section{Competing Interests}

The authors declare that they have no competing interests.

\section{Publisher's Note}

Veterinary World remains neutral with regard to jurisdictional claims in published institutional affiliation.

\section{References}

1. Wachirapakorn, C., Pilachai, K., Wanapat, M., Pakdee, P. and Cherdthong, A. (2016) Effect of ground corn cobs as a fiber source in total mixed ration on feed intake, milk yield and milk composition in tropical lactating crossbred Holstein cows. Anim. Nutr., 2(4): 334-338.

2. Yahya, A., Hasan, S., Natsir, A. and Nuhung, B. (2016) The effect of a different form of corn cob based complete feed on the consumption, characteristics, and ruminal fermentation on ruminants. Int. J. Sci. Basic Appl. Res., 30(5): 75-86.

3. Yulistiani, D., Puastuti, W., Haryanto, B., Purnomoadi, A., Kurihara, M. and Thalib, A. (2017) Complete rumen modifier 
supplementation in corn cob silage basal diet of lamb reduces methane emission. Indones. J. Agric. Sci., 18(1): 33-42.

4. Silva, A.E.M., de Lira, A.T., de Ferreira, M.A., de Barros, L.J.A., Melo, T., Siqueira, T.D.Q., Soares, L.F.P. and Costa, C. (2015) Sugarcane bagasse as roughage in sheep diet. Rev. Bras. Saude Prod. Anim., 16(1): 118-129.

5. Babiker, I.A., Mukhtar, A.M.S. and El Khidir, O.A. (2016) Digestibility and rumen degradability of bagasse based diets (BBD) feed to beef cattle. J. Dairy Vet. Anim. Res., 3(1): 15-18.

6. Filho, A.E., Carvalho, G.G.P., Pires, A.J.V., Silva, R.R., Santos, P.E.F., Murta, R.M., Pereira, F.M., Carvalho, B.M.A., Maranhao, C.M.A., Rufino, L.M.A., Santos, S.A. and Pina, D.S. (2016) Intake and ingestive behavior in lambs fed low-digestibility forages. Trop. Anim. Health Prod., 48(7): 1315-1321.

7. Galvani, D.B., Pires, A.V., Susin, I., Gouvea, V.N., Berndt, A., Abdalla, A.L. and Tedeschi, L.O. (2018) Net protein requirements and metabolizable protein use for growing ram lambs fed diets differing in concentrate level and roughage source. Small Rumin. Res., 165(2018): 79-86.

8. Eshag, N.A., Mohammed, B.H., Bukhari, S.A.S., Ali, M.A.M., and Jadallah, J.B., (2015) Effects of feeding groundnut shells enriched with protein and energy on feed intake, nutrients digestibility and weight change of Sudanese Desert lambs. J. Agric. Nat. Resour. Sci., 2(3):537-542.

9. Heuzé, V., Thiollet, H., Tran, G., Edouard, N., Bastianelli, D. and Lebas, F. (2016) Peanut Hulls. Feedipedia, a Programme by INRA, CIRAD, AFZ, and FAO. Available from: https:// www.agritrop.cirad.fr/582555/1/id582555.pdf. Retrieved on 05-01-2021.

10. Beigh, Y.A., Ganal, A.M. and Ahmad, H.A. (2017) Prospects of complete feed system in ruminant feeding: A review. Vet. World, 10(4): 424-437.

11. Heinrichs, J. and Kmicikewycz, A. (2016) Total Mixed Rations for Dairy Cows. Available from: https://www. extension.psu.edu/total-mixed-rations-for-dairy-cows. Retrieved on 12-01-2021.

12. Linn, J. (2021) Feeding Total Mixed Rations, College of Food, Agriculture and Natural Resource Science, University of Minnesota. Available from: https://www.extension. umn.edu/dairy-milking-cows/feeding-total-mixed-rations. Retrieved on 12-01-2021.

13. Karimizadeh, E., Chaji, M. and Mohammadabadi, T. (2017) Effects of physical form of diet on nutrient digestibility, rumen fermentation, rumination, growth performance and protozoa population of finishing lambs. Anim. Nutr., 3(2): 139-144.

14. Islam, R., Redoy, M.R.A., Shuvo, A.A.S., Sarker, M.A.H., Akbar, M.A. and Al-Mamun, M. (2017) Effect of pellet from total mixed ration on growth performance, blood metabolomics, carcass and meat characteristics on Bangladeshi Garole sheep. Prog. Agric., 28(3): 222-229.

15. Ishaq, S.L., Lachman, M.M., Wenner, B.A., Baeza, A., Butler, M., Gates, E., Ollvo, S., Geddes, J.B. and Yeoman, C.J. (2019) Pellet-hay alfalfa feed increases sheep wether weight gain and rumen bacterial richness over loosehay alfalfa feed. PLoS One, 14(6): e0215797.

16. Steel, R.G.D. and Torrie, J.H. (1991) Principles and Procedures of Statistics. $2^{\text {nd }}$ ed. PT Gramedia Pustaka Utama, Jakarta.

17. Hartadi H., Reksohadiprodjo, S. and Tillman, A.D. (2005) Tabel Komposisi Pakan Untuk Indonesia. Gadjah Mada University Press, Yogyakarta.

18. Farenzena, R., Kozloski, G.V., Gindri, M. and Stefanello, S. (2017) Minimum length of the adaptation and collection period in digestibility trials with sheep fed ad libitum only forage or forage plus concentrate. J. Anim. Physiol. Anim. Nutr., 101(5): 1057-1066.

19. Darlis, N.A., Halim, R.A., Jalaludin, S. and Ho, Y.W. (2000)
Effect of protein and carbohydrate supplements on feed digestion in indigenous Malaysian goats and sheep. AsianAustralas. J. Anim. Sci., 13(4): 464-469.

20. Pratiwi, N.M.W., Murray, P.J. and Taylor, D.G. (2007) Feral goats in Australia: A study on the quality and nutritive value of their meat. Meat Sci., 75(1): 168-177.

21. Santos, V.R.V., McManus, C., Peripolli, V., Tanure, C.B., Lima, P.M.T., Correa, P.S., Brito, D.L., Torres, S.E.F. and Louvandini, H. (2017) Dry matter intake, performance and carcass characteristics of hair sheep reared under different grazing systems. Sci. Agric., 74(6): 436-442.

22. Khan, A.A., Sai, M., Rao, B., Ravi, D., Prasad, K.V.S., Anandan, S., Reddy, Y.R. and Blummel, M. (2016) Effect of varying the crop residue, cultivar and physical form on intake and nutrient utilization in Deccani sheep fed complete diets. Anim. Nutr. Feed Technol., 16(2): 197-208.

23. Kishore, K.R., Kumar, D.S. and Rao, E.R. (2017) Prospects of total mixed ration (TMR) feeding in livestock production. Bull. Environ. Pharmacol. Life Sci., 6(3): 90-95.

24. Patil, A.K., Jain, R.K., Mehta, M.K., Agrawal, V., Choudhary, N.S., Jatav, G.P. and Karmore, S.K. (2019) Prospects of compressed complete feed blocks as ruminant feed for sustainable livestock production: A review. $J$. Entomol. Zool. Stud., 7(2): 1263-1267.

25. Sabbioni, A., Beretti, V., Zambini, E.M. and Superchi, P. (2016) Carcass and meat parameters in Cornigliese sheep breed as affected by sex and age-class. Ital. J. Anim. Sci., 15(1): 2-9.

26. Setyaningrum, A., Soeparno, S., Yusiati, L.M. and Kustantinah, K. (2015) Performance and meat quality of thin tailed sheep in supplementary feeding Lemuru fish oil protected by saponification with different $\mathrm{NaOH}$ concentration. Anim. Prod., 17(3): 177-185.

27. Obeidat, B.S., Mayyas, M.A., Abdullah, A.Y., Awawdeh, M.S., Qudsieh, R.I., Obeidat, M.D., Nusairat, B.M., Mahmoud, K.Z., Haddad, S.G., Al-Lataifeh, F.A., Ata, M., Ishmais, M.A.A. and Aljamal, A.E. (2019) The potential use of layer litter Awassi lamb diet: Its effect on carcass characteristics and meat quality. Animals, 9(10): 782.

28. Ponnampalam, E.N., Knight, M.I., Moate, P.J. and Jacobs, J.L. (2020) An alternative approach for sustainable sheep meat production: Implication for food security. $J$. Anim. Sci. Biotechnol., 11(2020): 83.

29. Saro, C., Mateo, J., Caro, I., Carballo, D.E., Fernandez, M., Valdes, C., Bodas, R. and Giraldez, F.J. (2020) Effect of dietary crude protein on animal performance, blood biochemistry profile, ruminal fermentation parameters and carcass and meat quality of heavy fattening Assaf lambs. Animals, 10(11): 2177.

30. Forwood, D.L., Holman, B.W.B., Hopkins, D.L., Smyth, H.E., Hoffman, L.C., Chaves, A.V. and Meale, S.J. (2021) Feeding unsaleable carrots to lambs increased performance and carcass characteristics while maintaining meat quality. Meat Sci., 173(2): 108402.

31. Valizadeh, A., Kazemi-Bonchenari, M., KhodaeiMotlagh, M., Moradi, M.H. and Salem, A.Z.M. (2021) Effects of different rumen undegradable to rumen degradable protein ratios on performance, ruminal fermentation, urinary purine derivatives, and carcass characteristics of growing lambs fed a high wheat straw-based diet. Small Rumin. Res., 197(2021): 106330.

32. Ripoll, G. and Panea, B. (2019) The effect of consumer involvement in light lamb meat on behavior, sensory perception, and health-related concerns. Nutrients, 11(6): 1200.

33. Ekiz, B, Yilmaz, A., Yalcintan, H., Yakan, A., Kocak, O. and Ozcan, M. (2019) The effect of production system and finish weight on carcass and meat quality of Kivircik Lambs. Ann. Anim. Sci., 19(2): 517-538. 